\title{
EDD - Economic Benefit Analysis of Extending Dry Docking Interval
}

\section{Dragan Bebića, Ladislav Stazićb ${ }^{\text {, Antonija Mišura }}{ }^{\mathrm{b}}$, Ivan Komar ${ }^{\mathrm{b}}$}

The possibility of interval extension between two dry docking is alternatively offered to the shipowners by classification societies. Although, for now, such a possibility is limited only to certain types of ships, a significant shift has been accomplished in accordance with today's technical and technological capacities. It is quite clear that not all shipowners will accept this option, as either five-year or even mid-interval might suit them well. The option introduces an economic benefit, but requires additional preparation to withstand the full interval without negative consequences, primarily related to the protection of underwater part of the hull. The relationship of economic benefits and the cost of investment to successfully pass the complete period gives a clear view to the shipowner for the decision of accepting an extended dry docking period between two consecutive dry dockings. This paper is presenting one of the approaches to calculate feasibility of prolonging dry docking interval. Calculation example represents an economic indicator, crucial for

\section{KEY WORDS}

$\sim$ Extending dry docking interval (EDD)

$\sim$ Composite coating, Underwater cleaning

$\sim$ Fuel consumption

$\sim$ Dry docking shipowner's decision to accept prolonged dry docking interval. The paper presents an analysis of underwater hull condition for the vessel with a composite coating. It is based on a collection of actual data registered in the period of seven years. Significant data have been derived from the analysis, allowing basic set up for theoretical assessment as well as the real justification of extended dry docking period between two consecutive dry dockings of the vessel. Some of the presented facts, related to underwater composite coating, might be used for similar calculations.

\section{INTRODUCTION}

Dry docking of the ship is an integral part of the regular maintenance of underwater hull, propeller, bow-thruster, sea water chests, cathodic protection of the hull, rudder, etc. Regular inspections in dry docks are specified by the IMO and classification societies, and they are usually accommodated within interval two and a half and five years. With the occurrence of the possibility to extend docking interval to the period of seven and a half years, although applicable only for certain types of vessels, a discussion opens in which interested sides present arguments for and against, to reconcile opinions. Namely, it is indisputable that today's technology enables most of the inspections and the repairs of the ship's underwater hull in a floating condition (Hydrex Underwater technology, 2012), and accordingly, it is quite justified to introduce extended docking interval. Viewing from the side of the ship-owner docking is "necessary evil", considering that the ship makes the profit only when sailing, the time spent in the dock, aside of maintenance costs, includes the costs of deviation to the shipyard as well as the costs of lost profits while staying in the shipyard. However, the counter-arguments are related to the application of a highquality underwater coating, and protection against the growth of the marine organisms. The efficiency of the ship's underwater hull coating is quite challenging for the five-year interval of 


\subsection{Analysis of extended period influence to the condition of the underwater hull}

For the task of analysis of underwater hull condition and its influence on the fuel consumption (Molland et al., 2011) in the extended period between dockings, processing of the data has been done for the vessel of 42,276 DWT. Fuel consumption and vessel's speed data had been collected within the period from February 2010 to August 2017. In this period, the vessel completed two dockings, 2011 and 2015. Surface treated composite coating had been applied to the underwater hull, for the first time in
2011, classified as STC (Surface Treated Composite) coating that neither contains nor release biocides, thus regular underwater cleaning is the only way to control fouling of the hull. During the second docking, $10 \%$ of the total coated area has been renewed on the flat bottom, vertical sides and bootop. It has to be noted that vessel's permanent trade is Nord Europe - Canada and that during winter period the coating is exposed to the mechanical damages by ice. Taking into consideration such severe condition, mentioned the percentage of the renewed coating is rather minimal. Presented graph (Figure 2) summarizes all data of fuel consumption and vessel's speed within the period 2010-2017.

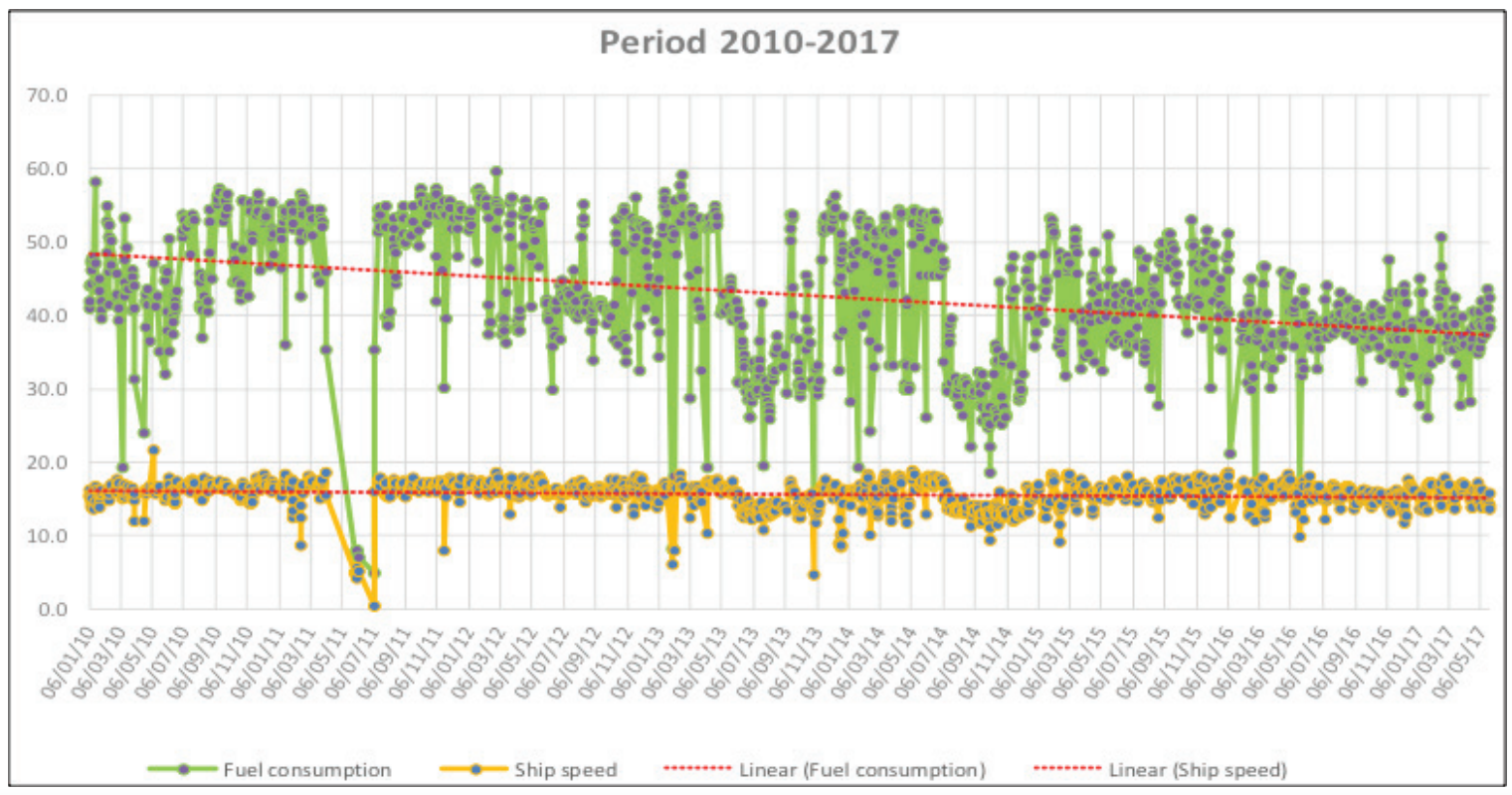

Figure 2.

Complete data for fuel consumption and ship speed in period 2010-2017.

Presented trends of fuel consumption and speed are linear, calculated by standard "Excel" functions. Linear equation for fuel consumption trend is:

$y=-0.0041 x+214.36$

where:

$x$ - quantity of the fuel for the specified date.

Accordingly, the regression coefficient of determination (Note: The specific indicator of regression reliability is coefficient of determination $\mathrm{R}^{2}$ that is, based on Chaddock's scale, within the range 0.0-1.0. The regression model is getting more reliable when the ratio of determination is closing value 1.0.) for fuel consumption $\left(R^{2}=0.1274\right)$ has been calculated. Based on Chaddock's scale (Table 1), its value is within range for low

reliable for fuel consumption prediction outside the observed interval.

Table 1.

Chaddock's scale (Moore et al., 2014).

correlation, and thus linear trend of fuel consumption is not

$\mathbf{R}^{2}$

0

$0.00-0.25$

$0.25-0.64$

0.64-1

1

IrI
0

\section{Explanation}

Negligible correlation Low correlation

Moderate correlation High correlation Very high correlation 
By using the same procedure, the equation of the linear trend of the ship speed and the regression coefficient of determination was obtained. Linear equation for ship speed trend is:

$y=-0.0003 x+28.233$

where:

$x$ - quantity of the fuel for the specified date.

The Regression coefficient of determination for speed data is 0.0152 .
Again, in case of ship's speed there is a weak connection data with the linear trend, even in this case, the pattern does not have enough accuracy for the speed prediction outside graph timeline. Anyhow, the intention of the paper is not to deal with the time prediction of consumption/speed of the ship, but with general direction of the trends during the observed data period. Therefore, a small value of the regression coefficient is acceptable. However, it should be taken into account that the graph (Figure 2) does not give a realistic picture as fuel consumption varies widely, due to the different sailing conditions:

- State of the substantial sea,

- Default full speed.

- Default economic speed

- Default super-economic speed

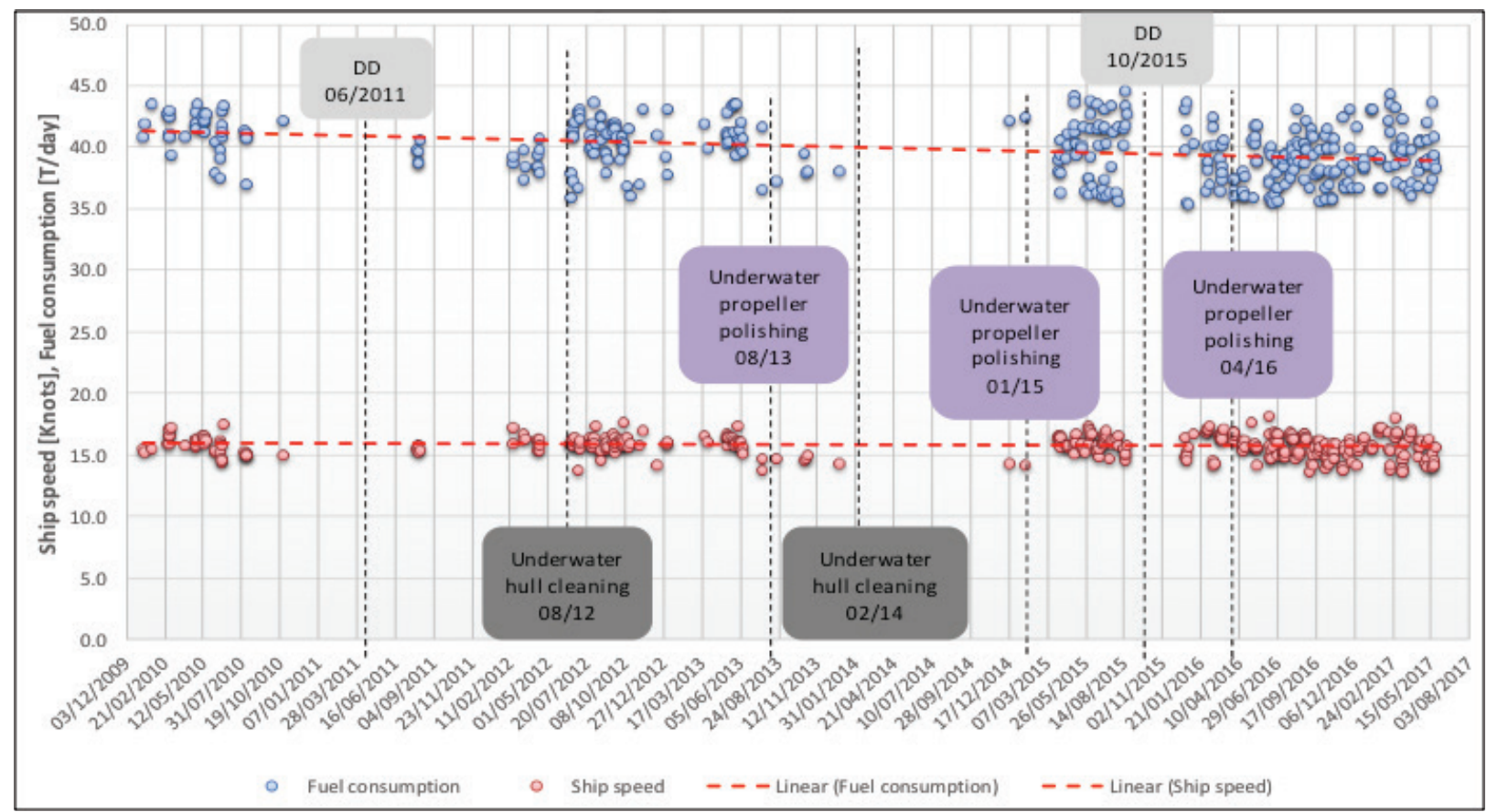

Figure 3.

Fuel consumption and speed data for ECO sailing regime in period 2010-2017.

Therefore, it is necessary to eliminate the data collected regarding heavy sea and choose one of the defaults sailing regimes throughout the interval 2010-2017. Data for navigating with economic speed are the most numerous, and it is quite logical to analyze these data.

Figure 3 shows only data for ECO (economical sailing speed) navigation, to better analyze the trend of speed and consumption (Kovanen, 2012). There are apparently defined time periods for maintenance of underwater hull and propeller, components that directly affect ship speed and fuel consumption (Logan, 2012).

\section{DISCUSSION}

The graphs are presented to determine the trends of fuel consumption and ship speed (International Organization for Standardization, 2016) in the indicated specified period to find out whether it is possible to extend the interval between the two dockings without significant loss of ship speed or increase in fuel consumption at the end of the extended range. In this case, ship speed is kept constant, so the change in fuel consumption is variable which characterizes economy of sailing. In this 
sense, at first glance, it is entirely illogical that the trend of fuel consumption tends to fall on all graphs. It is expected that the fuel consumption trend have a slight increase towards the end of the extended interval. Namely, since this underwater coating is hard and does not damage by underwater cleaning, the rotation of brushes to cleanse the collected marine organisms also polishes the underwater coat, and after each underwater cleaning, the roughness of the underwater coating becomes reduced.

For a rough estimate of fuel savings over the processing time, data from Figure 4 is used. The "Ton-Mile" trend starts with a value of 1.08 and ends with a value of 1.04.

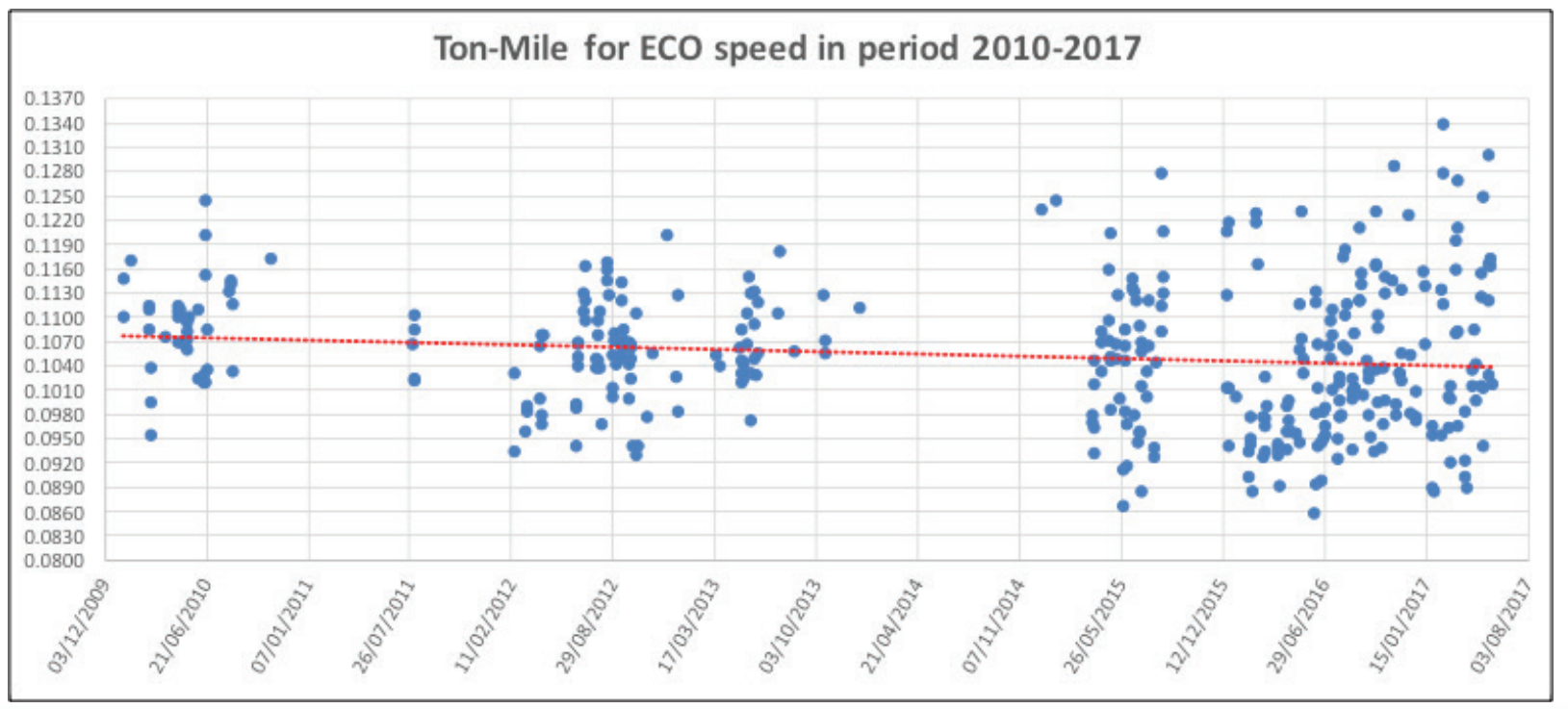

Figure 4.

Sailing distance in NM per one ton of consumed fuel.

From this, daily fuel consumption is calculated, considering that the "ton-mile" data used the average ship speed 15.8 knots.

"Ton - mile" $=\frac{\text { Daily fuel consumption }}{\text { Total daily distance sailed }}$

By adding known values, the daily fuel consumption is:

$$
0.108=\frac{x}{378.9}
$$

As per (4) daily fuel consumption at the beginning of the period is $40.9 \mathrm{~T} /$ day. By the same process, daily fuel consumption at the end of the period found to be 39.4 T/day.
In the case of quality classical biocide-releasing coatings, the average drop in ship speed at the end of the five-year period ranges from $0.5-0.8 \%$. As data for the vessel with a classical biocide-releasing coating is not available, comparison of two types of layers is not feasible. Therefore, the best possible case for the classic coating will be surmised, without speed drop and increased fuel consumption over the observed period that is based on average 252 sailing days per year for period 2010-2017. Figure 5 shows such a hypothetical example. A decrease in fuel consumption in the ship with a composite underwater coating is simplified and displayed linearly. At the very end of the period, the fuel consumption of the vessel with a composite marine coating is $3.67 \%$ lower than the ship with a classic underwater coat.

A decrease in fuel consumption in the ship with a composite underwater coating is simplified and displayed linearly. At the very end of the period, the fuel consumption of the vessel with a composite marine coating is $3.67 \%$ lower than the ship with a classic underwater coat. 


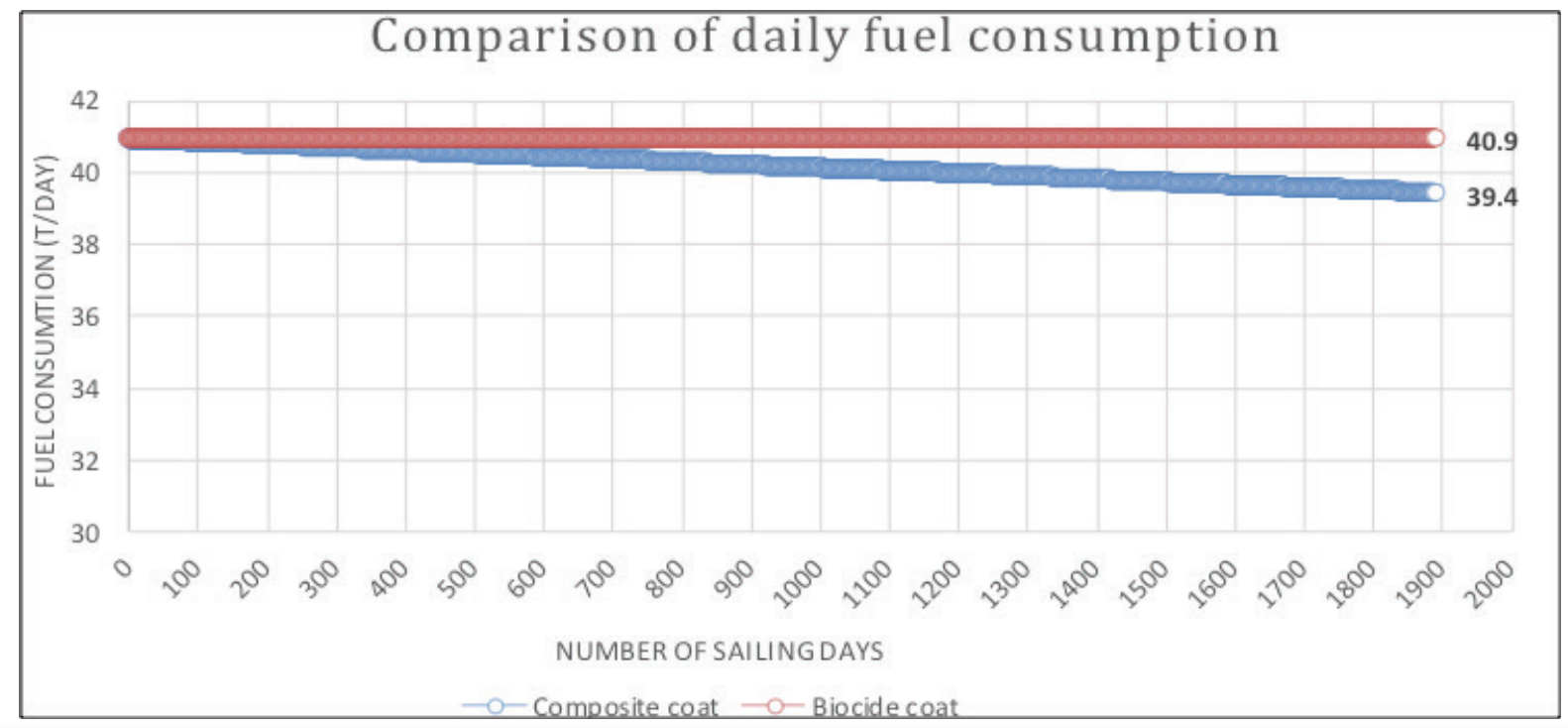

Figure 5.

Comparison of daily fuel consumption for vessels with composite and biocide coatings.

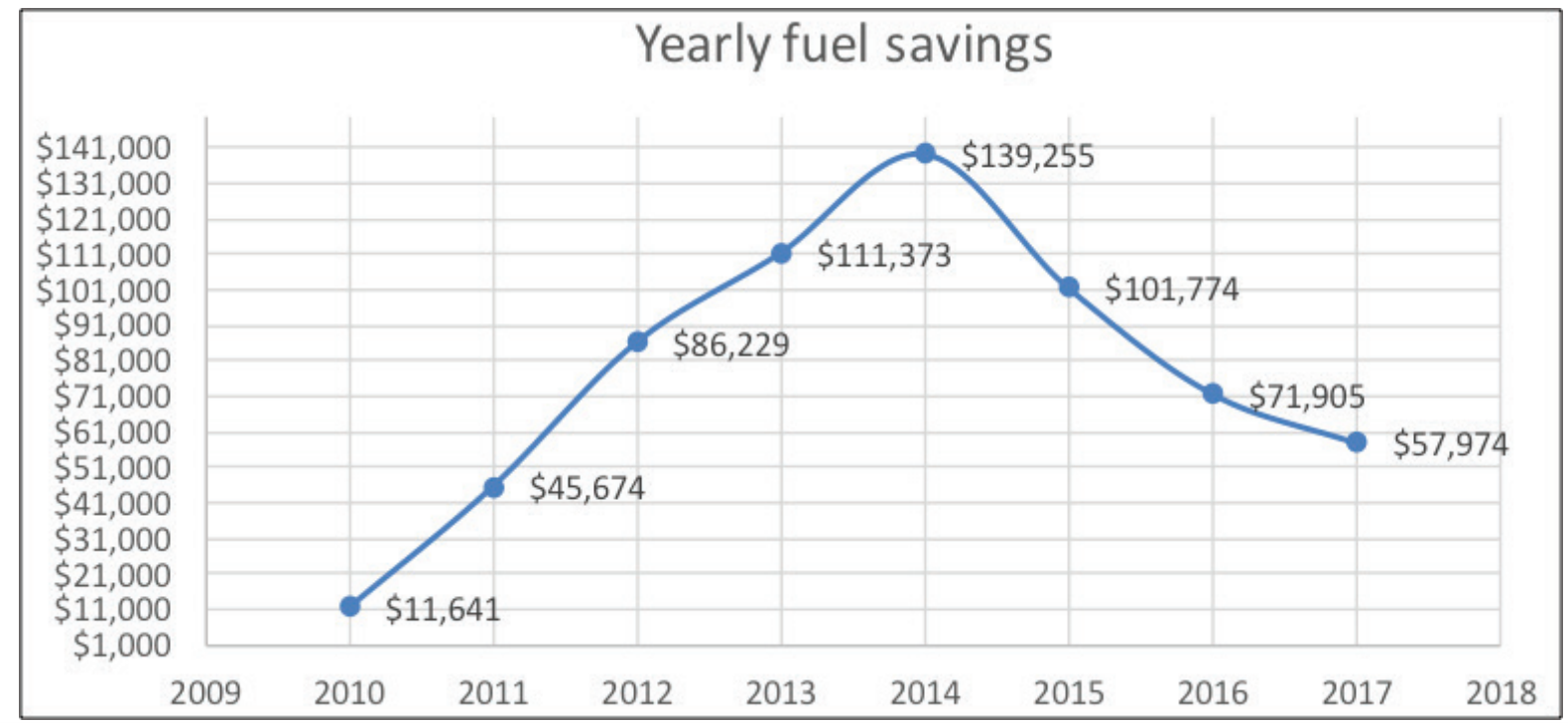

Figure 6.

Calculation of fuel savings for the ship with a composite underwater coating in relation to the fuel consumption of the ship with a classic coating.

For Figure 6, the assumption of a linear reduction in fuel consumption was used, starting from the initial consumption of 40.9 T/day to consuming $39.4 \mathrm{~T} /$ day at the end of the observed period. The calculation is based on the average fuel prices on the world market, as shown in Table 2.

During the observed seven-and-a-half year, total fuel savings on the vessel with a composite coating compared to the ship with a classic underwater layer is $1.62 \%$ or $\$ 625,825.00$. Comparative Table 3 greatly gives precedence to the vessel with a composite coat and confirms that the prolongation of the docking interval, in this case, is feasible and economically beneficial. However, it should be emphasized that a good part of the calculation is in the sphere of assumptions; thus, the conclusion has only theoretical potential. 
Table 2.

Fuel prices during observed period.

\begin{tabular}{|c|c|c|}
\hline $\begin{array}{l}\text { Average yearly fuel price at the world } \\
\text { market }\end{array}$ & Observed period & Source \\
\hline US 487.48 & 1st Oct $2009-1$ st Oct 2010 & LQM Petroleum Services, Inc. \\
\hline US 606.56 & 1st Oct 2010 - 1st Oct 2011 & LQM Petroleum Services, Inc. \\
\hline US 686.00 & 1st Oct 2011 - 1st Oct 2012 & LQM Petroleum Services, Inc. \\
\hline US 632.44 & 1st Oct 2012 - 1st Oct 2013 & LQM Petroleum Services, Inc. \\
\hline US 614.81 & 1st Oct 2013 - 1st Oct 2014 & LQM Petroleum Services, Inc. \\
\hline US 367.55 & 1st Oct $2014-1$ st Oct 2015 & ClearLynx LLC \\
\hline US 219.69 & 1st Oct 2015 - 1st Oct 2016 & ClearLynx LLC \\
\hline US 314.99 & 1st Oct 2016 - 1st Oct 2017 & ClearLynx LLC \\
\hline
\end{tabular}

The following assumptions have been used in this paper:

1. For the vessel with classical underwater coating

a. Data for ship speed and fuel consumption during the observed period were not available, so experience data applied (rebuilding underwater coating after five years).

b. It is incorrect assumption that there is no increased fuel consumption throughout the period. Most manufacturers, for quality classical coats, specify the average speed drop rate of $0.5-0.8 \%$ at the end of the interval. Incorporating the value of increased fuel consumption would additionally increase the overall cost of the ship with the classic coating in comparison with the vessel with a composite underwater layer.

Table 3.

Comparison of maintenance costs for underwater hull for the vessels with classical coating and the composite coating.

\begin{tabular}{|c|c|c|c|c|c|c|c|c|c|c|}
\hline & & $\begin{array}{l}\text { Initial } \\
\text { docking }\end{array}$ & 1st year & $\begin{array}{l}2 \text { nd } \\
\text { year }\end{array}$ & $\begin{array}{l}\text { 3rd } \\
\text { year }\end{array}$ & 4th year & 5th year & 6th year & 7th year & $\begin{array}{l}\text { End of } \\
\text { period }\end{array}$ \\
\hline \multirow{4}{*}{ 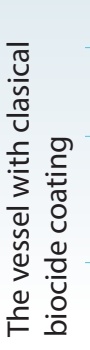 } & Cost for coating & $\$ 120,000$ & & & & & $\$ 100,000$ & & & \\
\hline & $\begin{array}{l}\text { Lost of profit due to } 12 \\
\text { days in SY }(\$ 22,000 / \text { dan })\end{array}$ & $\$ 264,000$ & & & & & $\$ 264,000$ & & & \\
\hline & $\begin{array}{l}\text { Cost of increased fuel } \\
\text { consumption due to } \\
\text { hull fouing }\end{array}$ & & & & & & & & & \\
\hline & $\begin{array}{l}\text { Total cost in observed } \\
\text { period }\end{array}$ & & & & & $\$ 748,00$ & & & & \\
\hline \multirow{5}{*}{ 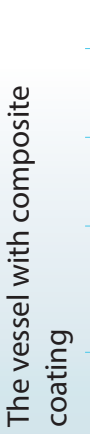 } & Cost for coating & $\$ 285,000$ & & & & & $\$ 40,000$ & & & \\
\hline & $\begin{array}{l}\text { Lost of profit due to } 12 \\
\text { days in SY }(\$ 22,000 / \text { dan })\end{array}$ & $\$ 264,000$ & & & & & 264,000 & & & \\
\hline & $\begin{array}{l}\text { Cost for underwater hull } \\
\text { cleaning }\end{array}$ & & $\$ 30,000$ & & & $\$ 30,000$ & $\$ 30,000$ & & & \\
\hline & $\begin{array}{l}\text { Fuel consumption } \\
\text { savings due to hull } \\
\text { cleaning }\end{array}$ & & $\$ 11,641$ & $\$ 45,674$ & $\$ 86,229$ & $\$ 111,373$ & $\$ 139,255$ & $\$ 101,774$ & $\$ 71,905$ & $\$ 57,974$ \\
\hline & $\begin{array}{l}\text { Total cost in observed } \\
\text { period }\end{array}$ & \multicolumn{9}{|c|}{$\$ 317,175$} \\
\hline
\end{tabular}


2. For the vessel with composite underwater coating a. The assumption is that the ship will retain the same performances and without second docking in 2015 (the assumption based on the trend).

b. The hull cleaning frequency is the actual data, but in some other sailing areas, such rate would not be sustainable without significant fouling of the hull. c. The lost profit due to time spent in the dock was in the calculation (actually there was), but in the extended interval, this cost does not exist.

Considering limited number of underwater hull cleanings (Table 3), a new Table 4 was created with the more realistic frequencies of underwater cleaning over the entire observed period.

Table 4.

Costs of maintaining a composite coating in case of increasing underwater cleaning frequency.

\begin{tabular}{|c|c|c|c|c|c|c|c|c|c|c|}
\hline & & $\begin{array}{l}\text { Initial } \\
\text { docking }\end{array}$ & 1st year & $\begin{array}{l}\text { 2nd } \\
\text { year }\end{array}$ & $\begin{array}{l}3 \text { rd } \\
\text { year }\end{array}$ & 4th year & 5th year & 6th year & $\begin{array}{l}\text { 7th } \\
\text { year }\end{array}$ & $\begin{array}{l}\text { End of } \\
\text { period }\end{array}$ \\
\hline \multirow{5}{*}{ 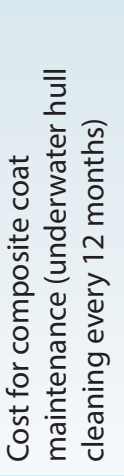 } & Cost for coating & $\$ 285,000$ & & & & & $\$ 100,000$ & & & \\
\hline & $\begin{array}{l}\text { Lost of profit due to } 12 \\
\text { days in } S Y(\$ 22,000 / \text { dan })\end{array}$ & $\$ 264,000$ & & & & & $\$ 264,000$ & & & \\
\hline & $\begin{array}{l}\text { Cost for underwater hull } \\
\text { cleaning }\end{array}$ & & $\$ 30,000$ & $\$ 30,000$ & $\$ 30,000$ & $\$ 30,000$ & $\$ 30,000$ & $\$ 30,000$ & $\$ 30,000$ & $\$ 30,000$ \\
\hline & $\begin{array}{l}\text { Fuel consumption } \\
\text { savings due to hull } \\
\text { cleaning }\end{array}$ & & $\$ 11,641$ & $\$ 45,674$ & $\$ 86,229$ & $\$ 111,373$ & $\$ 139,255$ & $\$ 101,774$ & $\$ 71,905$ & $\$ 57,974$ \\
\hline & $\begin{array}{l}\text { Total cost in observed } \\
\text { period }\end{array}$ & \multicolumn{9}{|c|}{$\$ 163,175$} \\
\hline \multirow{5}{*}{ 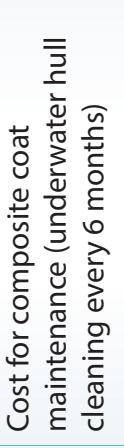 } & Cost for coating & $\$ 285,000$ & & & & & $\$ 40,000$ & & & \\
\hline & $\begin{array}{l}\text { Lost of profit due to } 12 \\
\text { days in } S Y(\$ 22,000 / \text { dan })\end{array}$ & $\$ 264,000$ & & & & & 264,000 & & & \\
\hline & $\begin{array}{l}\text { Cost for underwater hull } \\
\text { cleaning }\end{array}$ & & $\$ 60,000$ & $\$ 90,000$ & $\$ 60,000$ & $\$ 60,000$ & $\$ 60,000$ & $\$ 60,000$ & $\$ 60,000$ & $\$ 30,000$ \\
\hline & $\begin{array}{l}\text { Fuel consumption } \\
\text { savings due to hull } \\
\text { cleaning }\end{array}$ & & $\$ 11,641$ & $\$ 45,674$ & $\$ 86,229$ & $\$ 111,373$ & $\$ 139,255$ & $\$ 101,774$ & $\$ 71,905$ & $\$ 57,974$ \\
\hline & $\begin{array}{l}\text { Total cost in observed } \\
\text { period }\end{array}$ & \multicolumn{9}{|c|}{$\$ 403,175$} \\
\hline \multirow{5}{*}{ 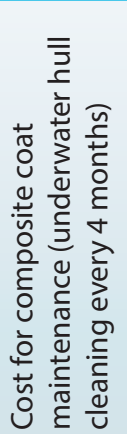 } & Cost for coating & $\$ 285,000$ & & & & & & & & \\
\hline & $\begin{array}{l}\text { Lost of profit due to } 12 \\
\text { days in SY }(\$ 22,000 / \text { dan })\end{array}$ & $\$ 264,000$ & & & & & & & & \\
\hline & $\begin{array}{l}\text { Cost for underwater hull } \\
\text { cleaning }\end{array}$ & & $\$ 90,000$ & $\$ 90,000$ & $\$ 90,000$ & $\$ 90,000$ & $\$ 90,000$ & $\$ 90,000$ & $\$ 90,000$ & $\$ 30,000$ \\
\hline & $\begin{array}{l}\text { Fuel consumption } \\
\text { savings due to hull } \\
\text { cleaning }\end{array}$ & & $\$ 11,641$ & $\$ 45,674$ & $\$ 86,229$ & $\$ 111,373$ & $\$ 139,255$ & $\$ 101,774$ & $\$ 71,905$ & $\$ 57,974$ \\
\hline & $\begin{array}{l}\text { Total cost in observed } \\
\text { period }\end{array}$ & & & & & $\$ 583,175$ & & & & \\
\hline
\end{tabular}


Table 4 presents three frequencies of hull cleaning that, based on experiential data, could be applied in the case of cold seas (12 months), combined sailing areas (6 months), and tropical seas (4 months). In all cases, the extended interval shows significant savings over the standard five-year docking period. These savings are:

- In the case of hull cleaning every 12 months, the total savings in the observed period for a ship with the composite underwater coating compared to the classic hull coat would amount to $\$ 584,825$.

- In the case of hull cleaning every 6 months, the total savings in the observed period for a ship with the composite underwater coating compared to the classic hull coat would amount to $\$ 344,825$.

- In the case of hull cleaning every 4 months, the total savings in the observed period for a ship with the composite underwater coating compared to the classic hull coat would amount to $\$ 164,825$.

\section{CONCLUSION}

A prolonged interval between the two dockings is the option offered by classification societies. It is quite clear that there will be contradictory opinions among shipowners, primarily related to the economic viability of the transition to an extended interval. Although this paper undoubtedly proved the economic viability of the change to the prolonged interval, the particularities of each case should account. For example, use of composite underwater coatings requires regular underwater cleaning as it is the only way to control the growth of marine organisms. Therefore, underwater cleaning should be available in the vessel's trading areas, according to maintenance plan of the hull. Unfortunately, the availability of ports that allows "classic" underwater cleaning is limited. Under "classic" underwater cleaning, it is considered the use of cleaning tools that do not collect products of cleaning, but they remain in the marine environment of the port. For a good reason this type of underwater cleaning become strictly prohibited in most of the ports around the world since, besides contamination of biocides from marine coatings, there is a great danger in the transmission of invasive marine organisms. However, this does not mean that underwater cleansing will be banished, on the contrary, underwater cleaning is a necessity as more and more ports do not accommodate vessels alongside if they have excessive hull fouling. Those vessels are forced to perform underwater hull cleaning before they can get alongside. However, this type of underwater cleaning means that all products of cleansing should collected and safely disposed outside marine environment. Unfortunately, such technology is not widely available, and this can be one of the arguments against the use of composite underwater coatings. In the case of biocidal coatings for an extended interval, which are not a unique brand of the coats, but conventional marine coating with an increased DFT (dry fil thickness), calculated to withstand extended interval. Most of the biocide underwater coat manufacturers have reserve towards a prolonged interval just because of the increased DFT, because with a significant increase in the thickness of the layer, the elasticity decreases and the possibility of cracking occurs and ultimately partial or complete destruction of the underwater coating of the hull is a likelihood. Considering all the above the extended interval has the potential of economic justification, but the process of deciding to switch to a prolonged interval must be well conceived and comprehensive in the analysis of all costs. Of great significance, for making the final decision, could be an analysis of the area and conditions of navigation of each ship separately.

\section{REFERENCES}

Bodilis, P., Francour, P., Langar, H., El Asmi, S., 2011. Non-native species in the Mediterranean: What, when, how and why?. United Nations Environment Programme (UNEP), Mediterranean Action Plan (MAP), Regional Activity Centre for Specially Protected Areas (RAC/SPA).

Carter C.D., 2009. Elimination of a ship source pollutant - STOP (Stern tube oil pollution). Proceedings of the 2009 Propulsion \& Emission Conference, Copenhagen, Denmark. Available at: http://thordonbearings.com/system/documents/ documents/116/original/WMTC2009_Thordon_Bearings_ver_2.pdf?1283356147, accessed on July 142018.

Det Norske Veritas AS., 2012. Classification notes No.72.2: Assessment of ships and managers for the acceptance of extended interval between bottom surveys in dry-dock. DNV-GL. Available at: http://rules.dnvgl.com/docs/pdf/DNV/cn/2012-05/ Cn72-2.pdf, accessed on: Jul 182018.

EPA, 2013. Available at: https://www.regulations.gov/document?D=EPA-HQ OW-2011-0141-0949, accessed on: Jul 222018.

Erich, S.J.F. \& Baukh, V., 2016. Modelling biocide release based on coating properties. Progress in Organic Coatings, 90, pp. 171-177. Available at:

http://dx.doi.org/10.1016/j.porgcoat.2015.10.009.

Hydrex Underwater technology, 2011. Clean Ship Hulls and Ports - Without Compromise. Hydrex White paper 3. Available at: http://ec.europa.eu/environment/ life/project/Projects/index.cfm?fuseaction=home.showFile\&rep=file\&fil=ECOTEC_ Clean_Ship_Hulls_and_Ports.pdf.

Hydrex Underwater technology, 2012. Extending the drydock interval. Quarterly Journal of Ship Hull Performance, 2(3), Available at: https://boudvanrompay.com/ upload/author/files/45debb37721757c22bed6531cceaa867.pdf.

International Organization for Standardization, 2016a. Ship and marine technology - Measurement of changes in hull and propeller performance - Part 1: General principles. ISO 19030-1:2016.

International Organization for Standardization, 2016b. Ship and marine technology - Measurement of changes in hull and propeller performance - Part 2: Default method, ISO 19030-2:2016.

International Organization for Standardization, 2016c. Ship and marine technology - Measurement of changes in hull and propeller performance - Part 3: Alternative methods, ISO 19030-3:2016 
Kovanen, L., 2012a. Methods for Hull and Propeller Performance Monitoring (Part 1). ENIRAM. Available at: https://www.eniram.fi/methods-for-hull-and-propellerperformance-monitoring-part-1, accessed on: Jul 172018.

Kovanen, L., 2012b. Hull Fouling - Study of hull fouling on cruise vessels across various seas. ENIRAM. Available at: https://www.eniram.fi/wp-content/uploads/2013/11/ Hull-fouling-study-1.12MB.pdf, accessed on: Oct 192018.

Lagersmit Corporation, 2018. The water lubricated floating sealing solution Available at: https://www.lagersmit.com/products/water-lubricated-floating-seal/, accessed on: Oct 192018

Logan, K.P., 2012. Using ship's propeller to detect hull fouling. ASNE Intelligent Ships Symposium IX. Philadelphia, USA. May 25.
Molland, A.F., Turnock, S.R., Hudson, D.A., 2011. Ship resistance and propulsion Practical estimation of ship propulsive power. Cambridge University press.

Moore, D.S., McCabe, G.P., Craig, B.A., 2014. Introduction to the practice of statistics. New York: W.H. Freemen \& Co.

N/D. at ENIRAM, 2012. Dynamic vs. Static trimming. Available at: http://www.eniram. fi/wp-content/uploads/2013/06/Dynamic-vs.-Static-Trim-paper-ID-24574.pdf, accessed on: Jul 242018.

Wärtsilä Corporation, 2018. Wärtsilä Envirosafe bearings. Available at: https:// www.wartsila.com/products/marine-oil-gas/seals-bearings/wartsila-sterntubesolutions/wartsila-water-lubricated-stern-tube-bearings, accessed on: Oct 192018. 